\title{
From the Epipalaeolithic into the earliest Neolithic (PPNA) in the South Levant
}

\author{
Anna Belfer-Cohen, Nigel Goring-Morris \\ Institute of Archaeology, The Hebrew University of Jerusalem, Jerusalem, IL \\ anna.belfer-cohen@mail.huji.ac.il; nigel.goring-morris@mail.huji.ac.il
}

\begin{abstract}
This paper examines the nature of initial neolithisation indications during the terminal Pleistocene and earliest Holocene in the Southern Levant. This interval corresponds to a period of significant and geographically variable environmental changes in the region. Various lines of evidence are provided to demonstrate the long durée ( 15000 years) character of interactions during the Early, Middle and Late Epipalaeolithic that were instrumental to the emergence of the fullyfledged agricultural life ways in the later phases of the Early Neolithic (PPNB).
\end{abstract}

KEY WORDS - Southern Levant; Epipalaeolithic; Natufian; Early Neolithic; cultural continuity

\section{Od epipaleolitika do \\ najzgodnejšega neolitika (PPNA) v južni Levanti}

\begin{abstract}
IZVLEČEK - V Članku raziskujemo naravo kazalcev začetne neolitizacije v času končnega pleistocena in najzgodnejšega holocena na območju južne Levante. V tem času je prišlo do pomembnih, vendar geografsko različnih okoljskih sprememb v regiji. Ponujamo različne dokaze o dolgoročni (ok. 15000 let) naravi interakcij v času zgodnjega, srednjega in poznega epipaleolitika, ki so bili ključni pri oblikovanju razvitih načinov poljedelstva v kasnejših obdobjih zgodnjega neolitika (PPNB).
\end{abstract}

KLJUČNE BESEDE - južna Levanta; epipaleolitik; Natufijska kultura; zgodnji neolitik; kulturna kontinuiteta

\section{Introduction}

Since the inception of research in Southwest Asia, the unique 'bridging' role of the Natufian culture1, between the 'Palaeolithic' and the 'Neolithic' (with all that such a role implies) has been widely acknowledged (Garrod 1932; Neuville 1934). The 'intermediate' nature of this entity - representing the shift from the preceding groups of mobile huntergatherers towards the following settled farming societies, especially in the Mediterranean zone - is reflected in many aspects of its material culture and lifeways (Fig. 1). There is, for the first time, evidence of long-term, semi-sedentary basecamp sites with substantial, durable structures accompanied by a largely microlithic knapped industry (Palaeolithic in nature), together with a heavy-duty component and sickle blades (heralding the chipped stone traditions of the Neolithic). Other distinctive features include cemeteries exhibiting complex burial rites, extensive groundstone and bone tool assemblages, and the appearance of artistic and symbolic manifestations as constant components of the material culture repertoire (see Bar-Yosef, Valla 1991; 2013; Cauvin 2000; Goring-Morris, Belfer-Cohen 2013a; Grosman, Munro 2017; Nishiaki et al. 2017; Shaham 2014; Yeshurun et al. 2014).

Yet, after many years of systematic research the terminology and processes involved in the transforma-

1 Originally considered as 'Mesolithic', nowadays it is attributed to the 'Late Epipalaeolithic' period, see Table 1. 
tion from the latest Natufian to the first Neolithic entities, namely the Pre-Pottery Neolithic A (PPNA; incorporating at least two cultural entities, the 'Khiamian' and the 'Sultanian') has been contentious and hotly debated (e.g., Abbès 2014; Bar-Yosef et al. 2010; Belfer-Cohen, Goring-Morris 1996; Crowfoot-Payne 1976; Garfinkel 1996; Gopher, Barkai 1997; Kuijt 1996, 1997; Nadel 1990; Ronen, Lechevallier 1999). Additionally, there has been increasing awareness that, at least in the Southern Levant, the criteria that justified the use of the term 'Neolithic Revolution' actually became apparent only with the shift from PPNA to PPNB (Goring-Morris, BelferCohen 2011a; 2016; and see below).

Initially, as is often the case in archaeology, it was assumed that the Neolithic 'package' was 'exotic' (i.e. allochthonous), having arrived from somewhere outside the region, as it was assumed that major changes as a rule occurred through external 'stimuli' (e.g., Kenyon 1957). Later, it was believed that during the latest Natufian phase there was a reversion to more mobile lifeways, brought about mostly due to the 'forcing' conditions of the supposedly harsh climatic Younger Dryas event (e.g., Grosman, Belfer-Cohen 2002; Moore et al. 2020). Still, it was assumed that the local Neolithic rose from the 'ashes' of the declining Natufian, without going into the specifics of how this came about, or the relation of the local southern Neolithic to the emergence of early Neolithic phenomena in the northern Levant (Belfer-Cohen, GoringMorris 2014; Cauvin 2000; Mellaart 1975). That the local Neolithic represents Natufian survival, 'by-theskin-of-their-teeth', is strengthened also by the presence of only a few sites with a unbroken Natufian - Neolithic sequence and the fact that most PPNA occurrences are found in different locations from the preceding major Natufian base camps (see $\mathrm{Bel}$ fer-Cohen, Goring-Morris 2010; Goring-Morris, Belfer-Cohen 2016 for details and references).
Current research has clearly demonstrated that there is solid evidence for local, in situ continuity between the two cultural manifestations. This is reflected by recent investigations of several 'Epi-Natufian' and 'Khiamian' settlements in the Mediterranean zone. ${ }^{2}$ Sites are mostly located at low elevations at the edge of the lower Jordan valley, i.e. Salibiya IX, Gilgal II, Huruk Musa and Nahal Ein Gev II (Dag, Goring-Morris 2010; Eitam et al. 2015; EnochShilo, Bar-Yosef 1997; Grosman et al. 2016; Rosenberg et al. 2010) and in the low-lying areas west of the central hill range, i.e. Nahal Oren, Tel Bareqet, Tzur Nathan, Kaizer, Qula and Hatoula (Grosman, Goren-Inbar 2007; Herzlinger et al. 2013; Khalaily, Marder 2010; Lechevallier, Ronen 1994; Marder et al. 2007; Paz et al. 2009; Ronen, Lechevallier 1991; Stekelis, Yisraely 1963; Zbenovich 2006), all dating to the interval of $c .12500-11600 \mathrm{cal} \mathrm{BP}$. The archaeology of those sites provides solid evidence of

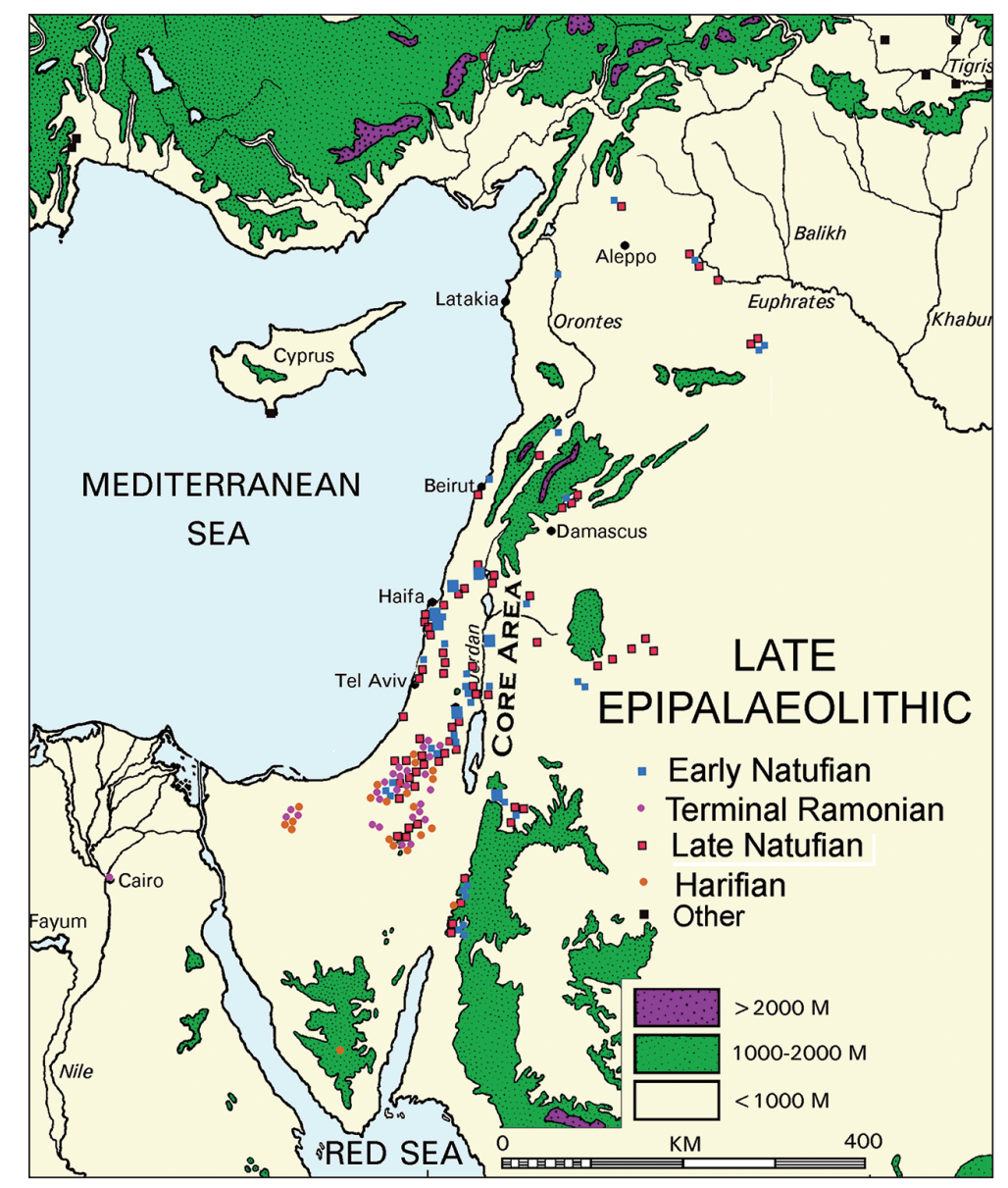

Fig. 1. Distribution of Late Epipalaeolithic (c. 15000-11600 cal BP) sites in the Levant: Early Natufian, Terminal Ramonian, Late Natufian, Harifian and 'Other'.

\footnotetext{
2 In the southern desert margins there appears to have been a virtual hiatus between the end of the Epipalaeolithic Harifian entity (= local variant of the Late/Final Natufian) and the initial PPNB (Goring-Morris 1991). Though see also the 'Epi-Harifian' of Abu Madi I in southern Sinai (Pomerantz-Greenblat 2014).
} 
local, endemic developments 'bridging' the end of the Natufian complex foragers' existence and the emergence of larger, clearly sedentary PPNA (Sultanian) settlements.

In attempting to understand the dynamics that operated to enable the appearance of what is considered to represent the initial Neolithic, it is necessary to refer to the Early and Middle Epipalaeolithic. Indeed, quite a number of 'Natufian-cum-Neolithic' characteristics appear much earlier, already by the Early Epipalaeolithic, with the onset of the Last Glacial Maximum (LGM; and see Table 1). This said, we shall present rather briefly the processes believed to be instrumental in shaping the Natufian entity, and which apparently continued into the Neolithic. Clearly, some of what will be presented is rather speculative, but we do rely on evidence to that effect in the archaeological record. We should clarify that we adhere to and point out the separation between longterm and short-term trends taking place throughout the entire Epipalaeolithic sequence.

\section{The Early and Middle Epipalaeolithic (Figs. 2, 4)}

The effects of the LGM appear to have differed between the Mediterranean zone (cold and wet) and areas further to the south (cold and dry) due to changes in the configuration, tracks and intensities of the winter storms ('Cyprus lows') over the eastern Mediterranean (Bar-Matthews et al. 1999; Enzel et al. 2008; though see Miebach et al. 2016). With the onset of the Early Epipalaeolithic, c. 25000 cal BP, a long-term trend of steady demographic growth is notable in the Southern Levant, continuing thereafter (Goring-Morris, Belfer-Cohen 2011a.Fig. 2; Grosman 2005; Stutz et al. 2009). Concurrent with the increase in population there was shrinkage in the scale and scope of the ranges/territories of specific Epipalaeolithic groups, when a variety of different entities can be identified based upon the stylistic proclivities of the chipped stone assemblages (BelferCohen, Goring-Morris 2011; Goring-Morris 1995; Leplongeon, Goring-Morris 2018; Marder, Goring-
Morris in press). These processes were not linearly accumulative, since they were also affected by changing environmental circumstances, including the global rise of sea levels and the drop in Lake Lisan levels reflecting significant changes in the ratio if precipitation $v s$. evaporation (Lisker et al. 2010; Torfstein et al. 2013).

With the beginning of an amelioration following the LGM, c. 20/19 000 cal BP, the formerly arid south 'opened up', and the Middle Epipalaeolithic entities emerged, expanding throughout the Levant (GoringMorris, Belfer-Cohen 2019). It was against this background of long durée processes that short-term trends were observed amongst the more specific and immediate interactions of the various mobile foraging groups inhabiting the region.

It is in the context of the early Epipalaeolithic Masraqan entity (Tab. 1) that there is already direct evidence for the extensive use of small-grained seeds and the cultivation and harvesting of cereals in the Southern Levant (Arranz-Otaeguia et al. 2016; Groman-Yaroslavski et al. 2016; Piperno et al. 2004; Snir et al. 2015a; 2015b). Although this evidence derives from only one site, Ohalo II, it can be reasonably assumed that these practices occurred on a small-scale in other (Early and Middle) Epipalaeolithic communities, at least in the Mediterranean region. This is also the period when quantities of pounding and grinding stones are first documented (Belfer-Cohen, Hovers 2005; Rosenberg 2008).

The sizes of mobile bands of Palaeolithic foragers are commonly thought to comprise $\sim 25$ individuals. In order to sustain genetically viable populations, the minimum mating pool should have included $\sim 250$ individuals, necessitating contacts with $\sim 10$ other groups, at least on a periodic basis (Birdsell 1968; Wiessner 1974; Wobst 1975). The presence of massive aggregation sites, i.e. Kharaneh IV and Jilat 6 (Garrard, Byrd 2013; Maher, Conkey 2019; Maher et al. 2011; 2016), spanning the later Early and the beginning of the Middle Epipalaeolithic (c. $19500-$

\begin{tabular}{|llll|}
\hline Period & Cultural Entities & cal BP & Duration Years \\
\hline Early Epipalaeolithic & Masraqan, Nebekian, Kebaran, Nizzanan & $\sim 25000-19000$ & $\sim 6000$ \\
\hline Middle Epipalaeolithic & Geometric Kebaran, Mushabian, Ramonian & $\sim 18500-15000$ & $\sim 3500$ \\
\hline Late Epipalaeolithic & Natufian, Terminal Ramonian, Harifian & $\sim 15000-11650$ & $\sim 3350$ \\
\hline PPNA & Khiamian, Sultanian & $\sim 11650-10600$ & $\sim 1050$ \\
\hline PPNB & Early, Middle, Late, Final PPNB & $\sim 10600-8350$ & $\sim 2250$ \\
\hline
\end{tabular}

Tab. 1. Chronological scheme of terminal Pleistocene and early Holocene cultural entities in the Southern Levant. 
$18500 \mathrm{cal} \mathrm{BP}$ ), encompassing several sociocultural entities in eastern Transjordan, are clearly important in this regard. They by far exceed the sizes of earlier or indeed contemporary occupations elsewhere in the Southern Levant. This novel means of social interaction would have fostered groups' ties at a larger scale than previously (Belfer-Cohen, Goring-Morris 2017).

Formerly thought to be strategically located for the interception of migratory herds of gazelle, recent preliminary isotopic evidence indicates that the prey were non-migratory, and instead thrived in large herds within the local steppic environment (Henton et al. 2017; 2018). Nevertheless, the size and scope of the occupations do indicate the (seasonal?) aggregation of bands from throughout much of the region, as reflected in the large quantities of marine molluscs recovered, which derive from both the Red and Mediterranean Seas (Richter et al. 2011; and see Byrd et al. 2016 for modelling of the ranges of such groups).

The various archaeological entities (identified on the basis of stylistic techno-typological criteria) of the Early and Middle Epipalaeolithic are generally de-

Fig. 2. Artistic and symbolic items from the Levantine Epipalaeolithic. Early Epipalaeolithic: A Urkan-e-Rubb II; B Qashish; C-D Kharaneh IV; 0 Jiita. Late Epipalaeolithic (Early \& Late Natufian): E Wadi Hammeh 27; F, G, R, V Eynan (Ain Mallaha); H, U el-Wad; I Upper Besor 6; J, L Hayonim Cave; K, P, S Fazael VI; M Raqefet Cave; N Hayonim Terrace; T Nahal Ein Gev II; (Harifian) Q Ramat Harif. After: Copeland, Hours 1977; Edwards et al. 2013; Garrod 1936-1937; Garrod, Bate 1937; Hovers 1990; Maher et al. 2012a; 2012b; Noy 1986; Perrot 1960; 1966; Rosenberg et al. 2020; Valla 2019; Valla et al. 2012; Yaroshevich et al. 2016. Photos: Nigel GoringMorris, Gabi Laron, Alexander Marshack - Archives of Institute of Archaeology, The Hebrew University of Jerusalem. Note different scales. marcated both chronologically and geographically; the latter is especially observable when comparing the Mediterranean and the arid areas of the Southern Levant. Thus one can follow through the archaeological record the spatial movements of groups pertaining to one entity or the other (e.g., BelferCohen, Goring-Morris 2011). With the shift to the Middle Epipalaeolithic, as environmental conditions improved, the Geometric Kebaran techno-complex was initially dispersed throughout the northern and Southern Levant (Bar-Yosef, Belfer-Cohen 1989; BarYosef, Meadow 1995; Goring-Morris 1987; 1995). Coevally, the earlier phase of the Mushabian technocomplex was restricted only to the Negev and Sinai. Later, the Geometric Kebarans seemingly disappeared from the south, in our opinion 'evicted' by the Mushabians and their descendants, the Ramonians, albeit while continuing to thrive in the north within the Mediterranean zone (Goring-Morris 1987; 1995).
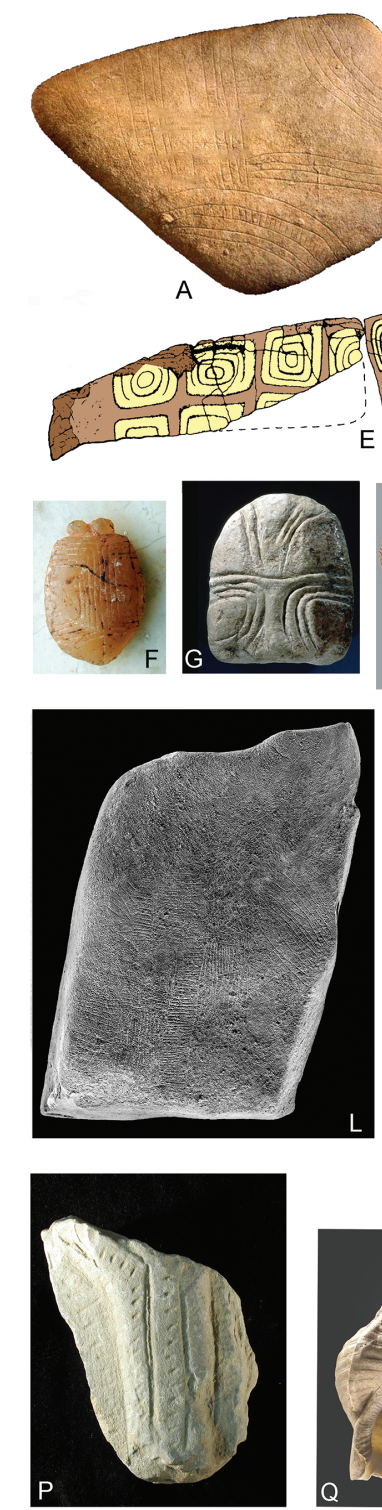

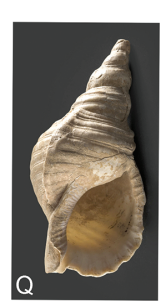

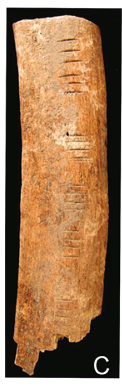
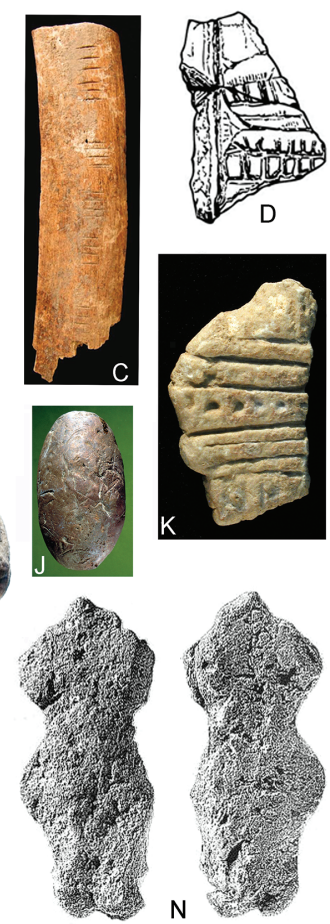

N
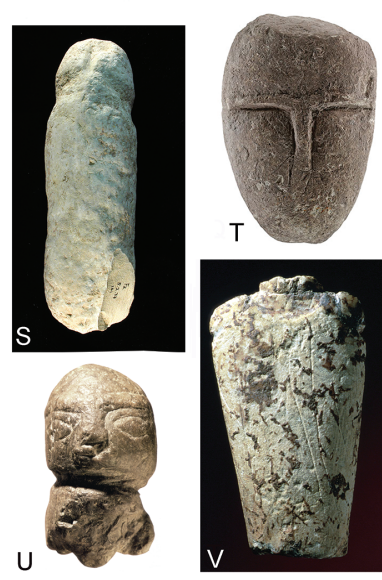
Matters changed, however, with the emergence of the Late Epipalaeolithic Natufian, which apparently spread throughout the Southern and Northern Levant, with observable adjustments to the particularities of each phytogeographic zone (as reflected in the different phases and facies of the entity) (Ashkenazy 2014; Belfer-Cohen, Goring-Morris 2013).

Though most of the material culture remains from the Early and Middle Epipalaeolithic are the lithic assemblages, the retrieved material also comprises bone tools, a groundstone industry, ochre and shells as well as artistic-cum-symbolic manifestations, which though rare, are more frequent than in the preceding Upper Palaeolithic entities (e.g., Gregg et al. 2011; Hovers 1990; Kaufman 1999; Muheisen 1988; Rabinovich, Nadel 1995; Richter et al. 2011; Yaroshevich et al. 2016; and see Belfer-Cohen, Goring-Morris in press).

\section{The Late Epipalaeolithic (Figs. 1-4)}

It seems that the encounters during the later Middle Epipalaeolithic between the Geometric Kebarans and the Mushabians/Ramonians were instrumental in the emergence of the Natufian techno-complex (dated to the Late Epipalaeolithic, from c. $15000 \mathrm{cal}$ BP onwards), with its distinctive features, to be found throughout the Southern Levant and beyond. How did this come about?

We hypothesize that the Geometric Kebarans were 'pushed out' of the Negev and Sinai in the south, where they are seemingly documented for only a short duration, retreating northwards into the Mediterranean zone, back to their 'ancestral' territories that they traditionally shared with those Geometric Kebaran bands which had continued to exploit the lusher regions of the Southern Levant, perhaps 'bearing with them gifts' from the south (also see below).

Under such circumstances (Mediterranean Geometric Kebaran communities facing the presence of Geometric Kebaran 'refugees' from the south), there would have been two options:

(1) Either the 'newcomers' were rejected and left to their 'gruesome' fate; or,
(2) They were accepted by the local communities, with whom they most probably continued to have shared a mating pool.

We believe that the available prima facie archaeological evidence tends to favour the latter scenario. Accordingly, individual Geometric Kebaran group sizes increased, requiring re-alignments in the spatial configurations of their territories, reflecting higher population densities and contraction into smaller territories than previously (Belfer-Cohen, GoringMorris 2013; Goring-Morris, Belfer-Cohen 2013a). While there is no evidence in the Mediterranean zone for aggregation sites on the scale seen previously during the earlier Epipalaeolithic (see above) ${ }^{3}$, it seems that still other social mechanisms would have had to be initiated in order to ensure inter-community contacts and thus retain a sufficiently large mating pool.

Indeed one can observe certain characteristics that clearly derived from the south and were incorporated into the Natufian cultural repertoire, being introduced (rather than 'imposed'), individually or within single groups. An obvious example of this is the use of the microburin technique (mbt) in some Natufian sites, while absent from others (Bar-Yosef, Valla 1979; Henry 1974). Indeed, we believe that the mbt - used systematically during the Nebekian, Nizzanan and Mushabian (and including in the Negev/Sinai and eastern Transjordan) to shape microliths, but unknown in the Mediterranean Kebaran and Geometric Kebaran, was now introduced to some Mediterranean Natufian communities. 4

It seems that there was a need to deal both with the 'external' changes in groups' subsistence resources (necessitated by changes in territory sizes and population densities), as well as with the 'inner' social alterations affected by increased numbers of group members, some of whom were the 'newcomers' from the south. Even though the changes affected some groups more than others, overall one can observe a 'domino' effect that ultimately impacted the entity as a whole. Signalling and symbolling increased significantly, as is apparent in the rich assemblages of artistic manifestations in many Natufian sites (e.g., Major 2018; Nadel, Langyel 2009; Orrel-

\footnotetext{
3 In the semi-arid Negev highlands, the Rosh Horesha/Saflulim site complex may represent a Late Natufian aggregation site (GoringMorris et al. 1999) that likely reflects the more mobile adaptation of this local facies due to environmental factors as opposed to coeval Natufian communities in the Mediterranean zone.

4 While, as a rule the Geometric Kebarans did not use the mbt technique habitually, there are sporadic instances in the Negev of unusual assemblages with Geometric Kebaran-like typological forms, i.e. trapeze/rectangle variants, fabricated using the mbt at Shluhat Qeren II, amongst other sites (Goring-Morris 1987.170).
} 
le 2014; and references therein). All of these may contribute to explaining the appearance of those novel elements distinguishing the Natufian from its predecessors, making it unique among the Epipalaeolithic entities; still, some of these elements continued to be shared with the immediately ensuing Neolithic (PPNA - c. 11600 cal BP).
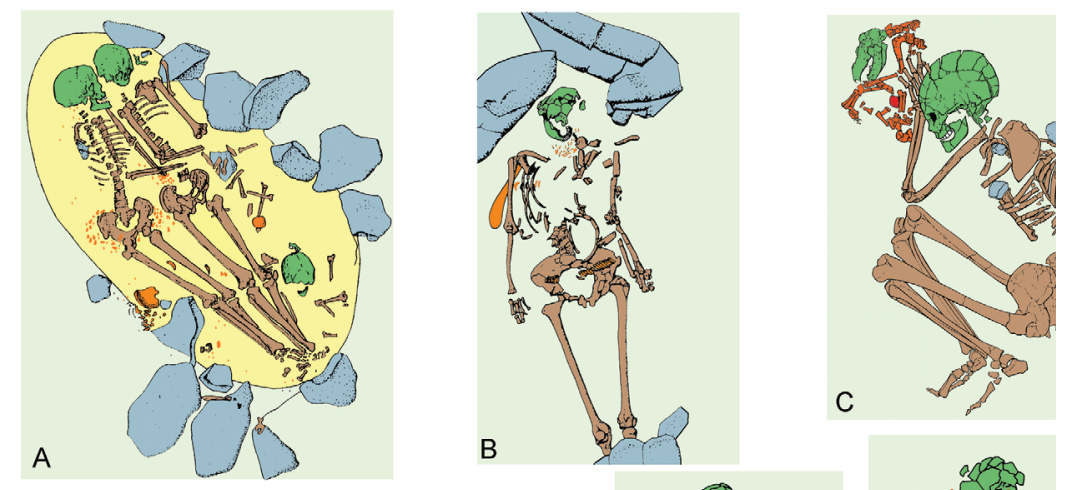

At the same time, the Natufians retained features and characteristics of their preceding ancestors. Moreover, detailed studies have revealed that, in fact, quite a few of the 'Neolithic hallmarks' are deeply rooted in the cultural realms of the Epipalaeolithic entities, even the earlier ones ( $\mathrm{Go}^{-}$ ring-Morris, Belfer-Cohen 2016; Belfer-Cohen, Goring-Morris in press).

It seems that by following the distinct and specific trajectory of the evolution of Natufian 'existence', we can start to unwrap the beginnings of the PPNA. Thus one can observe in the Natufian that:

(1) As communities became increasingly sedentary there were opportunities to accumu-
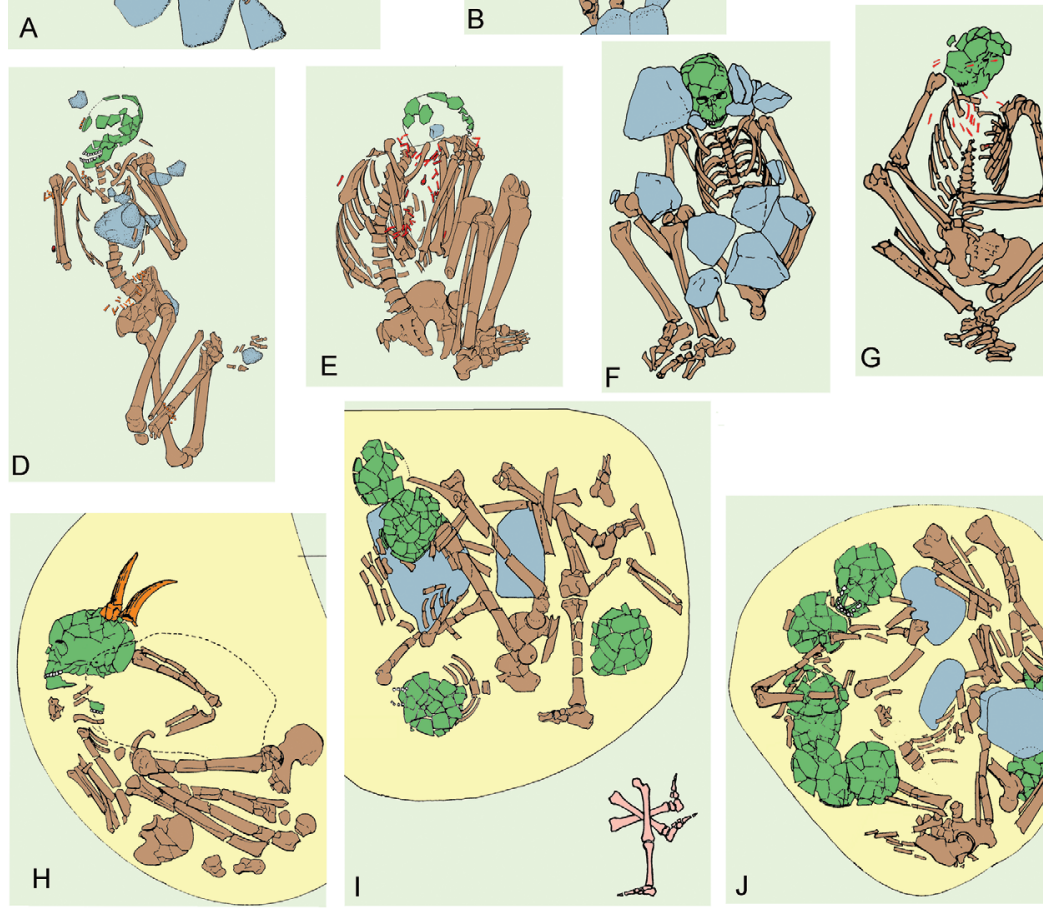

Fig. 3. Early (A-G) and Late Natufian (H-J) burials. A-B Hayonim Cave; C-G, H-J Eynan (Ain Mallaha - note arrangement of three legs in I. All decorations and grave goods are in orange. (Modified after BelferCohen 1988; Perrot, Ladiray 1988). Note different scales. late more 'stuff' (i.e. material belongings).

(2) As communities increased in size there was a necessity to develop novel social mechanisms to regulate the increasingly complex nature of interpersonal, intra-community and inter-community interactions.

3 The growing intra- and inter-group densities dictated more marked distinctions among the various communities comprising the Natufian entity as a whole.

Most immediately, many of these phenomena were expressed in the archaeological record, including a desire for 'exotics', and investments in the decorative and symbolic aspects of both non-utilitarian and mundane artefacts. The latter was expressed, among other ways, by the distinct stylistic 'signatures' of specific communities (Belfer-Cohen 1991; BelferCohen, Goring-Morris 2013; Noy, Brimer 1980; Ro- senberg et al. 2020; Shaham 2014; Shaham, Belfer-Cohen 2013; Shaham, Grosman 2019; Torres et al. 2020).

The processes enumerated above continued into the PPNA, evolving and changing through time (as had already occurred during the course of the 4000 year sequence of the Natufian), accompanied by increased interactions with entities further afield (e.g., Khalaily, Valla 2013).

Indeed, similarities and continuities are manifested in a wide range of material culture realms. Thus with regard to the constructed environment a number of architectural concepts continued, with the ongoing use of semi-subterranean circular structures. Indeed, it was only with the transition to the PrePottery Neolithic B (PPNB) that the shift to quadrilateral concepts in the Mediterranean zone is observ- 
ed, culminating in the Middle PPNB (e.g., Banning 1998; Goring-Morris, Belfer-Cohen 2013b). We believe that the appearance of obvious communal structures in the PPNA is, in a way, the culmination of mostly social processes evolving during the course of the Natufian.

A unique Natufian phenomenon observed in the Mediterranean region is the 'return to the caves' (BarYosef, Martin 1981; Belfer-Cohen, Goring-Morris 2009; Goring-Morris, Belfer-Cohen 2010), namely the intensive use of caves for special activities, $e . g$., burial grounds, ceremonies, feasting, etc., as illustrated by the Hilazon Tachtit cave (Grosman, Munro 2007, 2016; Grosman et al. 2008; Munro, Grosman 2010), Hayonim cave (Belfer-Cohen, Bar-Yosef 2012) and Raqefet cave (Nadel et al. 2013). Perhaps this restricted use of caves by members of particular Natufian groups reflects communal activities that would later take place during the Neolithic in communal, 'public' buildings (see Hayden 2012). Indeed it is of interest to note that during the Natufian, large-scale structures are first observed in its early stages; yet they disappear from

Fig. 4. Epipalaeolithic exchange items. A-B, G-H, J-L Natufian; C, F Harifian; D, E Kebaran and Geometric Kebaran. A Kebara Cave (flint 'lunates'); B Hayonim Cave, Eynan and el-Wad (jewelry - bone, shells and exotic minerals); C Shluhat Harif (green metamorphic handstone); D, E Karaneh IV (marine - Red and Mediterranean Seas - molluscs); F Ramat Harif (turquoise pendant); G Hayonim Cave (Mediterranean scaphopod beads); H-I Eynan (obsidian blade/bladelets and exotic green stone ornaments); J Hayonim Cave; K Eynan; L Kebara Cave (non-local basalt groundstone items). Photos after: Bar-Yosef Mayer, Zohar 2010; Khalaily, Valla 2013; Maher et al. 2012a; Richter et al. 2011; Archives of Institute of Archaeology, The Hebrew University of Jerusalem. Note different scales. the later architectural repertoire, perhaps replaced by the activities in the caves, as the examples above all pertain to the Late/Final Natufian. It is of interest to note that the kiva-type structure, 075, at PPNA Wadi Faynan 16 (WF16) provides similarities with the large-scale structures at (early) Natufian Eynan (L131) and Wadi Hammeh 27 (Edwards 2013; Finlayson et al. 2011; Haklay, Gopher 2015; Mithen et al. 2018; Valla 1988). Clearly, continuity is also observed in the artistic manifestations (Shaham, Grosman 2019).

The funerary practices provide an apt example of such a clear continuity between the Natufian and PPNA. Mostly because of the detailed data available, but also because these practices reflect processes and beliefs that are not impacted directly by the physical surroundings (as opposed to the more mundane as-
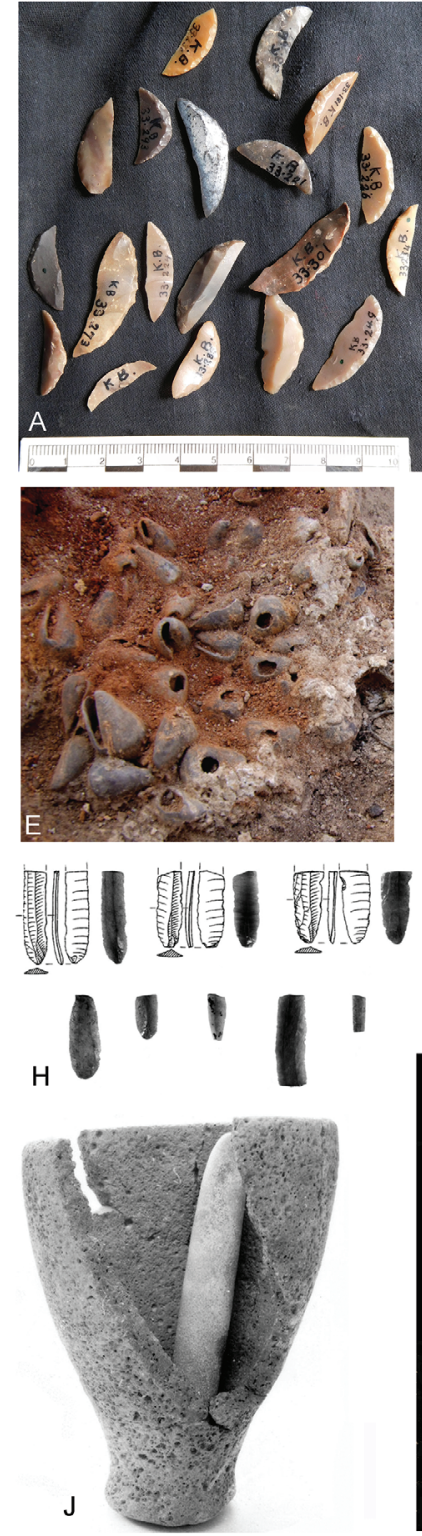
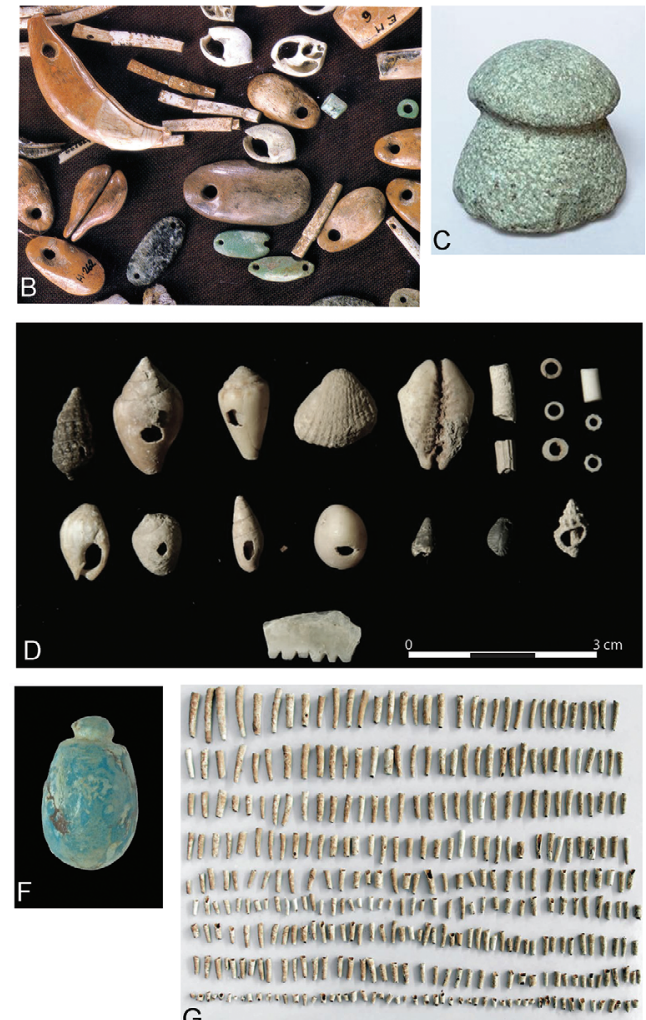

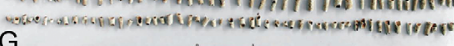
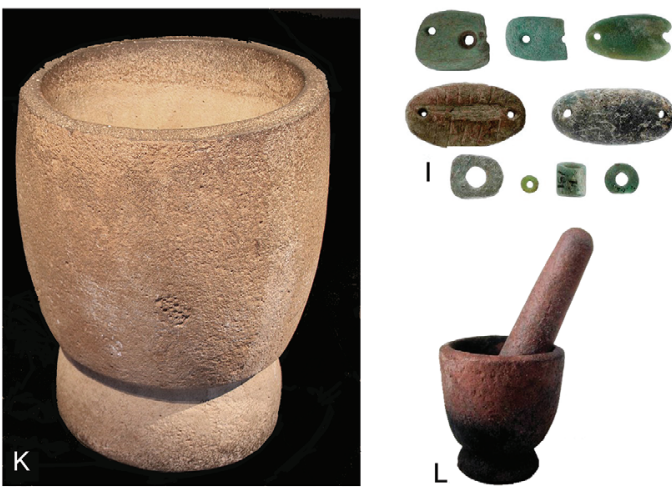
pects of daily existence, such as the availability of food resources). Clearly there were various processes already developing during the course of the Natufian (suffice it to note the disappearance of decorated burials in the Late, as opposed to the Early Natufian, and the rise in the practice of skull removal). Cemeteries emerged in designated areas within Natufian habitation sites, a phenomenon already apparent in its initial stages in the Geometric Kebaran (Maher et al. 2011). By the Natufian, the funerary practices included dedicated architecture, as exemplified by the funerary structure of 'Habitation' 1 at Eynan (Ain Mallaha), which is quite different from domestic structures with its plastered bench and upright monoliths (Perrot, Ladiray 1988). It is during the later Natufian that dedicated burial sites emerged, e.g., Hilazon Tachtit, Raqefet and $\mathrm{Na}$ hal Oren (Grosman, Munro 2016; Nadel et al. 2013; Noy 1993).

In terms of actual burial practices, PPNA burials follow patterns already documented during the Natufian - namely a variety of burial positions: single and multiple, primary (sometimes disturbed) and secondary burials; sometimes with grave markers; selective skull removal; few, if any personal decorations; re-arrangements of human bones; and unique burials (Croucher 2012; Goring-Morris, Belfer-Cohen $2013 c$; and references therein; and see Fig. 3).

Additionally, certain Natufian and PPNA funerary practices appear to herald subsequent developments during the PPNB, i.e. the likely appearance of foundation burials, as exemplified at Natufian Hilazon Tachtit (Grosman, Munro 2016) and PPNA Burial F8(298) at WF16 (Mithen et al. 2015). There are also other practices heralding the PPN, namely the use of 'pasty', plaster-type material to encase and/or cover burials, e.g., Natufian Nahal Ein Gev II (Friesem et al. 2019; Grosman et al. 2016) and PPNA WF16 (Mithen et al. 2015).

Continuity of practices is observed through cases of 'basket' and 'bundle' burials, the use of stone 'pillows' in graves, the decorative pigmentation of skulls, joint human/animal burials, as well as evidence for funerary feasting. Natufian examples of the above derive from Eynan (Perrot, Ladiray 1988), Nahal
Ein Gev II (Grosman et al. 2016), Azraq 18 (Bocquentin, Garrard 2016), Shubayka 1 (Richter et al. 2019), Hayonim Terrace (Valla 2012), and Hilazon Tachtit (Munro, Grosman 2010); the PPNA examples derive mainly from the site of WF16 (Mithen et al. 2015). In addition, the 'sitting' graves in the cemetery area at PPNA Hammeh are somewhat reminiscent of both those at the Early Epipalaeolithic Ain Qasiyah, Natufian Hayonim cave and the later PPNB burials at Tell Hallula on the Euphrates (Belfer-Cohen 1988; Guerrero et al. 2009; Makarewicz, Rose 2011; Richter et al. 2010).

Practices observed even earlier, in the Early Epipalaeolithic levels of Kharaneh IV (Maher et al. 2011; $2012 a$ ) are the introduction of animal horn cores as head adornments, found also in Natufian Eynan (Perrot, Ladiray 1988; and see Figure 3.H), and at PPNA Hatoula (Le Mort 1994; Goring-Morris, Belfer-Cohen 2011b)5. Another feature, quite enigmatic, relates to intentionally holed/pierced skulls, whether with a sizeable or narrow bored hole, observed as isolated cases all through the Natufian-PPNAPPNB sequence. One parsimonious hypothesis claims that the holes were intentionally bored post-mortem for suspending the skulls, based on observations made on a PPNB plastered skull from Jericho (Fletcher 2016). Intentional drilling of skulls (rather than excavation accidents) was also observed on Early Natufian (H25 at el-W, see Weinstein-Evron 2009) and Late Natufian individuals (H23 at Nahal Oren, see Dupouy-Madre, Crognier 1973), and has been reported in a number of personal observations 6 .

The rich symbolic/artistic repertoire of the Natufian (e.g., Major 2018 and references therein) can be described, for our purposes, as reflecting three components:

(1) general 'Natufian' features through time (phases); (2) local, site specific and regional particularities (facies); and

(3) long durée features evolving through time that continued into the Neolithic.

Illustrations of the latter include the appearance of artistic manifestations observed in Late Natufian sites in the Jordan Valley incorporating the use of

5 The accompaniment of horn cores with burials is documented both, earlier in the Late Upper Palaeolithic, at Nahal Ein Gev I (Arensburg 1977) and later in the PPNB (Locus 1304) at Kfar HaHoresh associated with a skull cache (pers. obs.).

6 A human cranium with a drilled hole in the parietal (for suspension?) was described from a LPPNB multiple grave (Loc. 1155) at Kfar HaHoresh (Simmons et al. 2007.17, Fig. 13b). This skull formed part of a deliberate spatial arrangement, perhaps in the form of a depiction. It also demonstrated evidence for perimortal trauma indicating that the individual may have been a victim of homicide. More recently, a similar phenomenon of a drilled skull was published from PPN Göbekli Tepe, supposedly as an innovation (Gresky et al. 2017). 
soft limestone/chalk as raw material, or incised patterns on bone and stone (e.g., Grosman et al. 2016; Hershman, Belfer-Cohen 2010; Shaham, Grosman 2019; and references therein), bead-spacers (BarYosef Mayer 2010) and the appearance of green beads (Bar-Yosef Mayer, Porat 2008). Accordingly, it seems likely that both the material culture of the Natufian and PPNA designate continuity and change pertaining to signalling and symbolism of a long durée nature, most probably indicating the lengthy process of the transformation before, and in parallel to, the economic 'turn-over' to fully agricultural practices.

Additionally, while there is already evidence during the earlier Epipalaeolithic for long distance exchange, e.g., marine molluscs (Bar-Yosef Mayer, Zohar 2010; Richter et al. 2011), during the course of the Natufian the range of items and sources involved in long-distance exchange increased significantly; this includes basalt for groundstone tools (Weinstein-Evron et al. 2001), flint (Delage 2013, 2018) and obsidian (Khalaily, Valla 2013), as well as green stone (Bar-Yosef-Mayer, Porat 2008). Source areas include the Nile Valley, Transjordan, the Mediterranean and Red Seas, western Sinai, northwestern Saudi Arabia, Cappadocia, as well as sources closer to home (Belfer-Cohen, Goring-Morris in press; Goring-Morris, Belfer-Cohen in press).

\section{Concluding remarks}

In exploring the shift in the Southern Levant from the Epipalaeolithic to the Neolithic we have suggested an apparent continuity, illustrating it with a few examples. Clearly, however, when checking the accumulating archaeological data, it becomes obvious that the processes of change were incremental and of long durée, the initial roots of which can be traced right back to at least the Early Epipalaeolithic, almost ten millennia prior to the emergence of the Natufian. Still, during the long and winding course of the Natufian and after, during the PPNA, cultural processes demonstrate major changes in life-ways in comparison to the preceding Palaeolithic. This is reflected at the level of the individual community, as well as within the region as a whole, and beyond. Ultimately, the available evidence indicates that the 'archaic' villages of the PPNA 'Sultanian' should be viewed as the culmination of developments beginning with the emergence of the Natufian, $c .15000$ cal BP ago, setting the backdrop against which the fully fledged agricultural villages of the subsequent PPNB emerged.
We have focused on data pertaining to Natufian PPNA continuity, primarily within the Mediterranean 'core area' (i.e. a 'linear', to some degree, process), ignoring other contemporaneous developments taking place farther afield in neighbouring areas, such as the appearance of the Harifian entity (c. 12 650-11 650 cal BP), with its particular adaptations to the arid Negev and Sinai (Goring-Morris 1991; Goring-Morris, Belfer-Cohen 2013a).

While geographically marginal, environmental changes in this area (i.e. the Younger Dryas event at 12 900-11 $600 \mathrm{cal} \mathrm{BP)} \mathrm{may} \mathrm{have} \mathrm{triggered} \mathrm{proces-}$ ses the impact of which reverberated throughout the broader region. Even if the Mediterranean zone itself was not involved (i.e. did not suffer from worsening conditions except to a limited degree, if at all), the phenomena taking place in the neighbouring, more arid, regions may also have indirectly impacted the Mediterranean zone. Indeed, we believe that the dynamics of such phenomena played a significant role in developments portraying the neolithisation processes (e.g., Watkins 2013), including actual movements of populations, such as the Late Epipalaeolithic/Early Neolithic colonization of Cyprus (Clarke 2014; Simmons 2014). These processes introduced new lifeways, new spiritual paradigms, and, when moving into territories already settled by indigenous populations, invoking what may be viewed as the cultural parallel of the biological force of 'hybridization vigour'.

Summing up all of the above, based on both the archaeological record and the way we currently understand cultural evolution (Henrich 2016 and references therein), one can conclude by stating that the Southern Levantine Neolithic phenomenon can be said to have arisen from the 'ashes' of the Natufian. It was triggered by processes, such as the tightening of previously established social networks, with distant 'cousins' from the periphery of the Natufian domain joining their kin in the Mediterranean region, in much the same manner as had occurred earlier with the transition from the Middle to the Late Epipalaeolithic (see above), emphasizing the notion that one must indeed be aware that not every change comes about through external triggers, and we have to take into consideration the impact of local dynamics and the effects of their accumulation.

We believe that this is a recurrent phenomenon, noted in diverse, far-flung regions, with different chronologies. Two recent publications come to mind to illustrate this statement, one being concerned 
with explaining the emergence of the Neolithic in Britain (Ray, Thomas 2018), while the other explores the much debated later appearance of the Hyksos in the Nile delta (Stantis et al. 2020).
ACKNOWLEDGEMENTS

The generous support of ISF Grant \#471/17 is gratefully acknowledged.

\section{References}

Abbès F. 2014. Bal'as: un autre scénario de la néolithisation du Proche-Orient (The Bal'as Mountains: a different scenario of the Near Eastern neolithization). In C. Manen, T. Perrin, and J. Guilaine (eds.), La Transition Néolithique en Méditerranée - The Neolithic transition in the Mediterranean. Errance. Paris: 13-27.

Arranz-Otaeguia A., Colledge S., Zapatac L., Teira-Mayolinid L. C., and Ibáñez J. J. 2016. Regional diversity on the timing for the initial appearance of cereal cultivation and domestication in southwest Asia. Proceedings of the $\mathrm{Na}$ tional Academy of Sciences of USA 113(49): 1400114006. https://doi.org/10.1073/pnas.1612797113

Arensburg B. 1977. New Upper Palaeolithic human remains from Israel. Eretz Israel 13: $208^{*}-215^{*}$.

Ashkenazy H. 2014. Lithic Production Processes in the Late Natufian of Israel: Core Area vs. Periphery. Unpublished $\mathrm{PhD}$ thesis. The Hebrew University of Jerusalem. Jerusalem.

Banning E. B. 1998. The Neolithic Period. Triumphs of architecture, agriculture, and art. Near Eastern Archaeo$\operatorname{logy}$ 61(4): 188-237.

Bar-Matthews M., Ayalon A., Kaufman A., and Wasserburg G. J. 1999. The Eastern Mediterranean Paleoclimate as a Reflection of Regional Events: Soreq Cave, Israel. Earth and Planetary Science Letters 166(1-2): 85-95.

Bar-Yosef 0., Belfer-Cohen A. 1989. The origins of sedentism and farming communities in the Levant. Journal of World Prehistory 40(3): 447-498.

Bar-Yosef 0., Goring-Morris A. N., Gopher A., and Kozłowski S. K. 2010. Gilgal and Its Place among Early Neolithic Sites in the Levant. In 0. Bar-Yosef, A. N. Goring-Morris, and A. Gopher (eds.), Gilgal: Early Neolithic Sites in the Lower Jordan Valley. The Excavations of Tamar Noy. ASPR Monograph Series and David Brown/Oxbow. Oakville, CT: $297-327$.

Bar-Yosef 0., Martin G. 1981. Le problème de la "sortie des grottes" au Natoufien. Bulletin de la Société Préhistorique Française 78: 187-192.
Bar-Yosef O., Meadow R.H. 1995. The origins of agriculture in the Near East. In D. Price, G. Gebauer (eds.), Last Hunters, First Farmers: New Perspectives on the Transition to Agriculture. Schools of American Research Press. Santa Fe: 39-94.

Bar-Yosef O., Valla F. 1979. L'Evolution du Natoufien: Nouvelles Suggestions. Paléorient 5: 145-152.

(eds.) 1991. The Natufian Culture in the Levant. International Monographs in Prehistory. Ann Arbor.

(eds.) 2013. Natufian Foragers in the Levant. Terminal Pleistocene Social Changes in Western Asia. International Monographs in Prehistory. Ann Arbor.

Bar-Yosef Mayer D. E. 2010. Stone beads of the Gilgal sites. In O. Bar-Yosef, A. N. Goring-Morris, and A. Gopher (eds.), Gilgal: Excavations at Early Neolithic Sites in the Lower Jordan Valley. The Excavations of Tamar Noy. ASPR Monograph Series and David Brown/Oxbow. Oakville, CT: 223-237.

Bar-Yosef Mayer D. E., Porat N. 2008. Green stone beads at the dawn of agriculture. Proceedings of the National Academy of Sciences of USA 105(25): 8548-8551. https://doi.org/10.1073/pnas.0709931105

Bar-Yosef Mayer D. E., Zohar I. 2010. The role of aquatic resources in the Natufian Culture. Eurasian Prehistory 7(1): 31-45.

Belfer-Cohen A. 1988. The Natufian Graveyard in Hayonim Cave. Paléorient 14(2): 297-308.

1991. Art Items from Layer B, Hayonim Cave: A Case Study of Art in a Natufian Context. In 0. Bar-Yosef, F. R. Valla (eds.), The Natufian Culture in the Levant. International Monographs in Prehistory. Ann Arbor: 569588.

Belfer-Cohen A., Bar-Yosef 0. 2012. The Natufian in Hayonim Cave and the Natufian of the Terrace. In F. R. Valla (ed.), Les Fouilles de la Terrasse d'Hayonim (Israel) 1980-1981 et 1985-1989. De Boccard. Paris: 471-519. 
Belfer-Cohen A., Goring-Morris A. N. 1996. The Late Epipalaeolithic as the Precursor of the Neolithic: The Lithic Evidence. In S. K. Kozłowski, H-G. Gebel (eds.), Neolithic Chipped Lithic Industries of the Fertile Crescent and Their Contemporaries in Adjacent Regions. ex oriente. Berlin: 217-225.

2009. For the first time. Comments on papers in "Conversation on the Origins of Agriculture". Current Anthropology 50(5): 669-672.

2010. The initial Neolithic in the Near East: Why it is so difficult to deal with the PPNA. Mitekufat Haeven Journal of the Israel Prehistoric Society 40: 1-18.

2011. Becoming Farmers: The Inside Story. Current Anthropology 52(S4): S209-S220.

https://doi.org/10.1086/658861

2013. Breaking the mold: Phases and facies in the Natufian of the Mediterranean zone. In O. Bar-Yosef, F. R. Valla (eds.), Natufian Foragers in the Levant Terminal Pleistocene Social Changes in Western Asia. Monographs in Prehistory. Archaeological Series 19. Ann Arbor: 543-561.

2014. North and South - Variable trajectories of the Neolithic in the Levant. In B. Finlayson and C. Makarewicz (eds.), Settlement, Survey, and Stone: Essays on Near Eastern Prehistory in Honour of Gary Rollefson. ex oriente and CBRL. Berlin and London: 61-71.

2017. 'Moving around' and the evolution of corporate identities in the Late Epipalaeolithic Natufian of the Levant. In M. Benz, H.-G. K. Gebel, and T. Watkins (eds.), The Construction of Neolithic Corporate Identities. Proceedings of ICAANE9, Basle 2014. Studies in Early Near Eastern Production, Subsistence, and Environment 20. ex oriente. Berlin: 81-90.

https://www.exoriente.org/docs/00100.pdf

in press. The role of networks in the connectivity of the Levantine Epipalaeolithic. In S. Hansen, F. Klimscha, and Renn J. (eds.), Prehistoric Networks in the longue durée: Palaeolithic Innovations enabling the Neolithic Revolution. Topoi. Berlin.

Belfer-Cohen A., Hovers E. 2005. The Ground Stone Assemblages of the Natufian and Neolithic Societies in the Levant - Current Status. Journal of the Israel Prehistoric Society - Mitekufat Haeven 35: 299-308.

Birdsell J. B. 1968. Some predictions for the Pleistocene based on equilibrium systems among recent hunter-gatherers. In R. Lee, I. DeVore (eds.), Man the Hunter. Aldine Publishing Co. Chicago: 229-240.
Bocquentin F., Garrard A. 2016. Natufian collective burial practice and cranial pigmentation: A reconstruction from Azraq 18 (Jordan). Journal of Archaeological Science: Reports 10: 693-702.

https://doi.org/10.1016/j.jasrep.2016.05.030

Byrd B., Garrard A. N., and Brandy P. 2016. Modeling foraging ranges and spatial organization of Late Pleistocene hunter-gatherers in the Southern Levant - A least-cost GIS approach. Quaternary International 396: 62-78. https://doi.org/10.1016/j.quaint.2015.07.048

Cauvin J. 2000. The Birth of the Gods and the Origins of Agriculture. Cambridge University Press. Cambridge.

Clarke J. 2014. Cyprus during the Neolithic period. In M. Steiner, A. E. Killebrew (eds.), The Oxford Handbook of the Archaeology of the Levant (ca 8000-332 BCE). Oxford University Press. 0xford: 177-193.

Copeland L., Hours F. 1977. Engraved and Plain Bone Tools from Jiita (Lebanon) and Their Early Kebaran Context. Proceedings of the Prehistoric Society 43: 295301 .

Croucher K. 2012. Death and Dying in the Neolithic Near East. Oxford University Press. Oxford.

Crowfoot-Payne J. 1976. The terminology of the Aceramic Neolithic period in the Levant. In F. Wendorf (ed.), Deuxieme Colloque sur la Terminologie de la Préhistoire du Proche-Orient. IX Congres UISPP. Nice: 131-137.

Dag D., Goring-Morris A. N. 2010. The Epi-Natufian Occupation of Gilgal II. In 0. Bar-Yosef, A. N. Goring-Morris, and A. Gopher (eds.), Gilgal: Excavations at Early Neolithic Sites in the Lower Jordan Valley the Excavations of Tamar Noy. ASPR Monograph series and David Brown/ Oxbow. Oakville, CT: 121-138.

Delage C. 2013. Chert Procurement Patterns and Exploitation Territory: Case Study from Late Natufian Hayonim Terrace (Western Galilee, Israel). In 0. Bar-Yosef, F. R. Valla (eds.), Natufian Foragers in the Levant Terminal Pleistocene Social Changes in Western Asia. Monographs in Prehistory. Archaeological Series 19. Berghahn Books. Ann Arbor: 449-462.

2018. Revisiting Rolling stones: The procurement of non-local goods in the Epipaleolithic of the Near East. Quaternary International 464(Part A): 159-172. https://doi.org/10.1016/j.quaint.2017.07.023

Dupouy-Madre M., Crognier É. 1973. Les Natoufiens du Nahal Oren (Ouadi Fallah). Etude anthropologique. Paléorient 2(1): 103-121. 
Edwards P. C. (ed.) 2013. Wadi Hammeh 27, An early Natufian settlement at Pella in Jordan. Brill. Leiden and Boston.

Eitam D., Kislev M., Karty A., and Bar-Yosef 0. 2015. Experimental Barley Flour Production in 12,500-Year-0ld Rock-Cut Mortars in Southwestern Asia. PLOS ONE 10(7): e0133306. https://doi.org/10.1371/journal.pone.0133306

Enoch-Shiloh D., Bar-Yosef 0. 1997. Salibiya IX. In 0. BarYosef, A. Gopher (eds.), An Early Neolithic Village in the Jordan Valley Part I: The Archaeology of Netiv Hagdud. American School of Prehistoric Research Bulletin 43. Peabody Museum of Archaeology and Ethnology, Harvard University. Cambridge, MA: 13-40.

Enzel Y., Amit R., Dayan U., Crouvi O., Kahana R., Ziv B., and Saron D. 2008. The Climatic and Physiographic Controls of the Eastern Mediterranean over the Late Pleistocene Climates in the Southern Levant and its Neighboring Deserts. Global and Planetary Change 60(3-4): 165192. https://doi.org/10.1016/j.gloplacha.2007.02.003

Finlayson B., Mithen S. J., Najjar M., Smith S., Maričević D., Pankhurst N., and Yeomans L. 2011. Architecture, sedentism, and social complexity at Pre-Pottery Neolithic A WF16, Southern Jordan. Proceedings of the National Academy of Sciences of USA 108(20): 8183-8188. https://doi.org/10.1073/pnas.1017642108

Fletcher A. 2016. From person to ancestor, the plastered skull from Jericho. Current World Archaeology 74: 24-26.

Friesem D., Abadi I., Shaham D., and Grosman L. 2019. Lime plaster cover of the dead 12,000 years ago - new evidence for the origins of lime plaster technology. Evolutionary Human Sciences 1(e9): 1-23.

https://doi.org/10.1017/ehs.2019.9

Garfinkel Y. 1996. Critical Observations on the So-Called Khiamian Flint Industry. In K. S. Kozłowski, H.-G. Gebel (eds.), Neolithic Chipped Stone Industries of the Fertile Crescent, and Their Contemporaries in Adjacent Region. ex oriente. Berlin: 15-21.

Garrard A. N., Byrd B. F. (eds.) 2013. Beyond the Fertile Crescent. Late Palaeolithic and Neolithic Communities of the Jordanian Steppe. The Azraq Basin Project. Oxbow Books. Oxford and Oakville.

Garrod D. A. E. 1932. A New Mesolithic Industry: The Natufian of Palestine. Journal of the Royal Anthropological Institute 62: 257-269.

1936-1937. Notes on Some Decorated Skeletons from the Mesolithic of Palestine. Annual of the British School in Athens 37: 123-127.
Garrod D. A. E., Bate D. M. A. 1937. The Stone Age of Mount Carmel. Excavations at the Wadi-Mughara. Clarendon Press. Oxford.

Gopher A., Barkai R. 1997. Here Are the Microliths: A Reply to "Where Are the Microliths?" Neo-Lithics 1(97): 1618.

Goring-Morris A. N. 1987. At the Edge: Terminal Pleistocene Hunter-Gatherers in the Negev and Sinai. British Archaeological Reports IS 361. Archaeopress. Oxford.

1991. The Harifian of the Southern Levant. In O. BarYosef, F. R. Valla (eds.), The Natufian Culture in the Levant. International Monographs in Prehistory. Archaeological Series 1. Berghahn Books. Ann Arbor: 173234.

1995. Complex hunter-gatherers at the end of the $\mathrm{Pa}$ leolithic (20,000-10,000 BP). In T. E. Levy (ed.), The Archaeology of Society in the Holy Land. Leicester University Press. London: 141-168.

Goring-Morris A. N., Belfer-Cohen A. 2010. Different Ways of Being, Different Ways of Seeing... Changing Worldviews in the Near East. In B. Finlayson, G. Warren (eds.), Landscapes in Transition: Understanding Hunter-Gatherer and Farming Landscapes in the Early Holocene of Europe and the Levant. Levant Supplementary Series 8. Oxbow Books. Oxford: 9-22.

2011a. Neolithization Processes in the Levant: The Outer Envelope. Current Anthropology 52(S4): S195S208. https://doi.org/10.1086/658860

2011b. Evolving human/animal interactions in the Near Eastern Neolithic: feasting as a case study. In G. Aranda, S. Montón and M. Sanchez (eds.), Guess who's coming to dinner. Feasting rituals in the prehistoric societies of Europe and Near East. Oxbow Books. Oxford: 64-72.

2013a. Ruminations on the role of periphery and centre for the Natufian. In 0. Bar-Yosef and F. R. Valla (eds.), The Natufian Foragers in the Levant Terminal Pleistocene Social Changes in Western Asia. Monographs in Prehistory. Archaeological Series 19. Ann Arbor. Michigan: 562-583.

2013b. Houses and Households: A Near Eastern Perspective. In D. Hofmann and J. Smyth (eds.), Tracking the Neolithic house in Europe - sedentism, architecture and practice. Springer. New York: 19-44.

2013c. Different strokes for different folks: Near Eastern Neolithic mortuary practices in perspective. In I. Hodder (ed.), Religion at Work in a Neolithic Society 
Vital Matters. Cambridge University Press. Cambridge: 35-57.

2016. The appearance of the PPNA in the Levant: Sudden? Gradual? And Where From? In Ü. Yalçın (ed.), Anatolian Metal VII - Anatolia and neighbours 10000 years ago. Der Anschnitt - Zeitschrift für Kunst und Kultur im Bergbau. Bochum: 185-198.

2019. Packaging the Levantine Epipalaeolithic. In C. McCartney, L. Astruc, F. Briois, and V. Kassianidou (eds.), Near Eastern Lithic technologies on the move: Interactions and contexts of development of Neolithic traditions. $8^{\text {th }}$ International Conference on PPN Chipped and Ground Stone Industries of the Near East Nicosia, Cyprus. Astrom Editions Limited. Uppsala: 429448.

in press. 'Supply-and-Demand': Networking in the Initial Neolithic of the Levant. In S. Hansen, F. Klimscha, and J. Renn (eds.), Prehistoric Networks in the longue durée: Palaeolithic Innovations enabling the Neolithic Revolu tion. Topoi. Berlin.

Goring-Morris A. N., Goldberg P., Goren Y., Baruch U., and Bar-Yosef D. 1999. Saflulim: A Late Natufian base camp in the central Negev highlands, Israel. Palestine Exploration Quarterly 131(1): 1-29.

https://doi.org/10.1179/peq.1999.131.1.36

Gregg M. W., Chazan M., and Janetski J. 2011. Variability in symbolic behaviour in the southern Levant at the end of the Pleistocene. Before Farming 2011(1): 1-12.

https://doi.org/10.3828/bfarm.2011.1.1

Gresky J., Haelm J., and Clare L. 2017. Modified human crania from Göbekli Tepe provide evidence for a new form of Neolithic skull cult. Science Advances 3(6): e1700564. DOI: 10.1126/sciadv.1700564

Groman-Yaroslavski I., Weiss E., and Nadel D. 2016. Composite Sickles and Cereal Harvesting Methods at 23,000Years-Old Ohalo II, Israel. PloS ONE 11(11): e0167151. https://doi.org/10.1371/journal.pone.0167151

Grosman L. 2005. Computer Simulation of Variables in Models of the Origins of Agriculture in the Levant. Unpublished PhD thesis. The Hebrew University of Jerusalem. Jerusalem.

Grosman L., Belfer-Cohen A. 2002. Zooming onto the 'Younger Dryas'. In R. T. J. Cappers, S. Bottema (eds.), The Dawn of Farming in the Near East. Studies in Early Ner Eastern Product ion, Subsistence, and Environment 6. ex oriente. Berlin: 49-54.

Grosman L., Goren-Inbar N. 2007. "Taming" Rocks and Changing Landscapes: A New Interpretation of Neolithic
Cupmarks. Current Anthropology 48(5): 732-740.

https://doi.org/10.1086/520966

Grosman L., Munro N. 2007. The sacred and the mundane: domestic activities at a Late Natufian burial site in the Levant. Before Farming 4: 1-14.

2016. A Natufian Ritual Event. Current Anthropology 57(3): 311-331. https://doi.org/10.1086/686563

2017. The Natufian Culture. The Harbinger of Food-Producing Societies. In Y. Enzel, and O. Bar-Yosef (eds.), Quaternary Environments, Climate Change, and Humans in the Levant. Cambridge University Press. Cambridge: 699-707.

Grosman L., Munro N. D., Abadi I., Boaretto E., Shaham D., Belfer-Cohen A., and Bar-Yosef 0. 2016. Nahal Ein Gev II, a Late Natufian community at the Sea of Galilee. Plos ONE 11(1): 1-32.

https://doi.org/10.1371/journal.pone.0146647

Grosman L., Munro N. D., and Belfer-Cohen A. 2008. A 12,000-year-old Shaman burial from the southern Levant (Israel). Proceedings of the National Academy of Sciences of USA 105(46): 17665-17669.

https://doi.org/10.1073/pnas.0806030105

Guerrero E., Molist M., Kuijt I., and Anfruns J. 2009. Seated Memory: New Insights into Near Eastern Neolithic Mortuary Variability from Tell Halula, Syria. Current Anthropology 50: 379-391. https://doi.org/10.1086/598211

Haklay G., Gopher A. 2015. A new look at Shelter 131/51 in the Natufian site of Eynan (Ain-Mallaha), Israel. PloS ONE 10(7): e0130121.

https://doi.org/10.1371/journal.pone.0130121

Hayden B. 2012. Corporate Groups and Secret Societies in the Early Neolithic. A Comment on Hodder and Meskell. Current Anthropology 53(1): 126-127.

https://doi.org/10.1086/663331

Henrich J. 2016. The secret of our Success. How Culture is Driving Human Evolution, Domesticating Our Species, and Making Us Smarter. Princeton University Press. Princeton.

Henry D. 0. 1974. The Utilization of the Microburin Technique in the Levant. Paléorient 2(2): 389-398.

Henton E., Martin L., Garrard A., Jourdan A.-L., Thirlwall M., and Boles 0. 2017. Gazelle seasonal mobility in the Jordanian steppe: The use of dental isotopes and microwear as environmental markers, applied to Epipalaeolithic Kharaneh IV. Journal of Archaeological Science: Reports 11: 147-158.

https://doi.org/10.1016/j.jasrep.2016.11.031 
Henton E., Roe J., Martin L., Garrard A., Boles 0., Lewis J., Matthew T., and Jourdon A.-L. 2018. Epipalaeolithic and Neolithic gazelle hunting in the Badia of north-east Jordan. Reconstruction of seasonal movements of herds by stable isotope and dental microwear analyses. Levant 50(2): $127-172$.

https://doi.org/10.1080/00758914.2019.1598764

Hershman D., Belfer-Cohen A. 2010. "It's Magic!": Artistic and Symbolic Material Manifestations from the Gilgal Sites. In 0. Bar-Yosef, A. N. Goring-Morris and A. Gopher (eds.), Gilgal: Excavations at Early Neolithic Sites in the Lower Jordan Valley The Excavations of Tamar Noy. ASPR Monograph Series and David Brown/Oxbow. Oakville, CT: $185-216$.

Herzlinger G., Grosman L., and Goren-Inbar N. 2013. The PPNA quarry of Kaizer Hill, Modi'in, Israel - The waste piles. In F. Borrell, J. J. Ibáñez, and M. Molist (eds.), Stone Tools in Transition: From Hunter-Gatherers to Farming Societies in the Near East. Proceedings of the $7^{\text {th }}$ International Conference on the Chipped and Ground Stone Industries of the Pre-Pottery Neolithic. Universitat Autònoma de Barcelona Press. Barcelona: 395-405.

Hovers E. 1990. Art in the Levantine Epi-Palaeolithic: an engraved pebble from a Kebaran site in the lower Jordan Valley. Current Anthropology 31: 317-322. https://www.jstor.org/stable/2743634

Kaufman D. 1999. A Unique Engraved Object from the Epipalaeolithic of Israel. Rock Art Research 16(1): 109-112.

Kenyon K. M. 1957. Digging Up Jericho. Benn. London.

Khalaily H., Marder 0. 2010. Prehistoric Investigations along the Cross-Israel Highway: State of Research. 'Atiqot 64: 5-23.

Khalaily H., Valla F. 2013. Obsidian in Natufian Context: The Case of Eynan (Ain Mallaha), Israel. In O. Bar-Yosef, F. R. Valla (eds.), The Natufian Foragers in the Levant Terminal Pleistocene Social Changes in Western Asia. Monographs in Prehistory. Archaeological Series 19. Berghahn Books. Ann Arbor: 193-202.

Kuijt I. 1996. Where are the microliths? Lithic technology and Neolithic chronology as seen from the PPNA occupation at Dhra', Jordan. Neo-Lithics 2(96): 7-8.

1997. Interpretation, data and the Khiamian of the south-central Levant. Neo-Lithics 3(97): 3-6.

Lechevallier M., Ronen A. 1994. Le Gisement de Hatoula en Judée Occidentale, Israel. Association Paléorient. Paris.

Le Mort F. 1994. Les sepultures. In M. Lechevallier, A. Ronen (eds.), Le Gisement de Hatoula en Judée Occiden- tale, Israel. Memoires et Travaux du Centre de recherche Francais de Jerusalem No. 8. Association Paléorient. Paris: 39-57.

Leplongeon A., Goring-Morris A. N. 2018. Terminal Pleistocene lithic variability in the Western Negev (Israel): is there any evidence for contacts with the Nile Valley? Journal of Lithic Studies 5: 1-39.

https://doi.org/10.2218/jls.2614

Lisker S., Vaks A., Bar-Matthews M., Porat R., and Frumkin A. 2010. Late Pleistocene palaeoclimatic and palaeoenvironmental reconstruction of the Dead Sea area (Israel), based on speleothems and cave stromatolites. Quaternary Science Reviews 29(9-10): 1201-1211. https://doi.org/10.1016/j.quascirev.2010.01.018

Maher L. A., Conkey M. 2019. Homes for Hunters? Exploring the Concept of Home at Hunter-Gatherer Sites in Upper Paleolithic Europe and Epipaleolithic Southwest Asia. Current Anthropology 60(1): 91-137. https://doi.org/10.1086/701523

Maher L. A., MacDonald D. A., Allentuck A., Martin L., Spyrou A., and Jones M. D. 2016. Occupying wide open spaces? Late Pleistocene hunter-gatherer activities in the Eastern Levant. Quaternary International 396: 79-94. https://doi.org/10.1016/j.quaint.2015.07.054

Maher L. A., Richter T., Macdonald D., Jones M. D., Martine L., and Stock J. T. 2012. Twenty thousand-year-old huts at a hunter-gatherer settlement in Eastern Jordan. PLOS ONE 7(2): $e 31447$.

https://doi.org/10.1371/journal.pone.0031447

Maher L. A., Richter T., and Stock J. T. 2012. The Pre-Natufian Epipaleolithic: Long-Term Behavioral Trends in the Levant. Evolutionary Anthropology 21: 69-81. https://doi.org/10.1002/evan.21307

Maher L. A., Stock J. T., Finney S., Heywood J. J. N., Miracle P. T., and Banning E. B. 2011. A Unique Human-Fox Burial from a Pre-Natufian Cemetery in the Levant (Jordan). PLOS ONE 6(1): e15815.

https://doi.org/10.1371/journal.pone.0015815

Major J. 2018. Wadi Hammeh 27, Jordan Valley. Natufian Art Items. A Contextual Analysis. ex oriente. Berlin.

Makarewicz C. A., Rose K. 2011. Early Pre-Pottery Neolithic settlement at el-Hemmeh: A survey of the architecture. Neo-Lithics 1(11): 23-29.

Marder 0., Goring-Morris A. N. in press. The Lithic Technologies of the Epipaleolithic Hunter-Gatherers in the Negev, Israel: Implications from Refitting Studies. In A. Leplongeon, D. Pleurdeau, and M. Goder-Goldberger (eds.), Human occupations of the Nile Valley and neighbor- 
ing regions between 75,000 and 15,000 years ago. Scientific publications of the Museum National d'Histoire Naturelle France. Paris.

Marder 0., Goring-Morris A. N., Khalaily H., Milevski I., and Zbenovich V. 2007. Tzur Natan, a Pre-Pottery Neolithic A site in central Israel and observations on regional settement patterns. Paléorient 33(2): 79-100.

Mellaart J. 1975. The Neolithic of the Near East. Thames and Hudson. London.

Miebach A., Chen C., Schwab M. J., Stein M., and Litt T. 2016. Vegetation and climate during the Last Glacial high stand (ca. 28-22 ka BP) of the Sea of Galilee, northern Israel. Quaternary Science Reviews 156: 47-56. https://doi.org/10.1016/j.quascirev.2016.11.013

Mithen S., Finlayson B., Maricevic D., Smith S., Jenkins E., and Najjar M. 2015. Death and Architecture: The Pre-Pottery Neolithic A Burials at WF16, Wadi Faynan, Southern Jordan. In C. Renfrew, M. J. Boyd and I. Morley (eds.), Death Rituals, Social Order and the Archaeology of Immortality in the Ancient World: 'Death Shall Have No Dominion'. Cambridge University Press. Cambridge: 82110.

Mithen S., Finlayson B., Maričević D., Smith S., Jenkins E., and Najjar M. 2018. WF16 - Excavations at an Early Neolithic Settlement in Wadi Faynan, Southern Jordan. Stratigraphy, Chronology, Architecture and Burials. Council for British Research in the Levant. Oxford.

Moore A. M. T. and 13 co-authors. 2020. Evidence of Cosmic Impact J. H. at Abu Hureyra, Syria at the Younger Dryas Onset $(\sim 12.8 \mathrm{ka})$ : High-temperature melting at $>2200^{\circ}$ C. Scientific Reports 10(1): 4185.

https://doi.org/10.1038/s41598-020-60867-w

Muheisen M. 1988. The Epipalaeolithic Phases of Kharaneh IV. In A. N. Garrard and H.-G. Gebel (eds.), The Prehistory of Jordan. The State of Research in 1986. British Archaeological Reports IS 396(i). Archaeopress. Oxford: 353-367.

Munro N. D., Grosman L. 2010. Early Evidence (ca. 12,000 BP) for Feasting at a Burial Cave in Israel. Proceedings of the National Academy of Sciences of USA 107(35): 15362-15366. https://doi.org/10.1073/pnas.1001809107

Nadel D. 1990. The Khiamian as a case of Sultanian intersite variability. Journal of the Israel Prehistoric Society - Mitekufat Haeven 23: 86*-99*.

Nadel D., Danin A., Power R. C., Rosen A. M., Bocquentin F., Tsatskin A., Rosenberg D., Yeshurun R., Weissbrod L., Rebollo N. R., Barzilai 0., and Boaretto E. 2013. Earliest floral grave lining from 13,700-11,700-y-old Natufian bu- rials at Raqefet cave, Mt. Carmel, Israel. Proceeding of the National Academy of Sciences of USA 110(29): 1177411778. https://doi.org/10.1073/pnas. 1302277110

Nadel D., Lengyel G. 2009. Human-made bedrock holes (mortars and cupmarks) as a late Natufian social phenomenon. Archaeology Ethnology and Anthropology of Eurasia $37(2)$ : 37-48.

https://doi.org/10.1016/j.aeae.2009.08.012

Neuville R. 1934. Le Préhistorique de Palestine. Revue Biblique 43: 237-259.

Nishiaki Y., Yoneda M., Kanjou Y., and Akazawa T. 2017. Natufian in the north: The Late Epipalaeolithic cultural entity at Dederiyeh Cave, northwest Syria. Paléorient 43(2): 7-24. https://doi.org/10.3406/paleo.2017.5763

Noy T. 1986. The Natufian Culture. In K. Howard (ed.), Treasures of the Holy Land Ancient Art from the Israel Museum. The Metropolitan Museum of Art. New York: 31-40.

1993. Oren, Nahal. In E. Stern (ed.), The New Encyclopedia of Archaeological Excavations in the Holyland. The Israel Exploration Society and Carta. Jerusalem: 1166-1170.

Noy T., Brimer B. 1980. Adornment of Early Natufian burials. Israel Museum News 16: 55-64.

Orrelle E. 2014. Material images of humans from the Natufian to Pottery Neolithic periods in the Levant. British Archaeological Reports IS 2595. Archaeopress. Oxford.

Paz Y., Paz S., and Shimelmitz R. 2009. An incised stone object from the PPNA of Tel Bareqet, Ayalon. Neo-Lithics 02(09): 29-30.

Perrot J. 1960. Excavations at Eynan (Ain Mallaha): Preliminary report on the 1959 season. Israel Exploration Journal 10(1): 14-22.

1966. Le Gisement Natoufien de Mallaha (Eynan), Israel. L'Anthropologie 70(5-6): 437-483.

Perrot J., Ladiray D. 1988. Les Hommes de Mallaha (Eynan), Israel. Association Paléorient. Paris.

Piperno D. R., Weiss E., Holst I., and Nadel D. 2004. Processing of wild cereal grains in the Upper Palaeolithic revealed by starch grain analysis. Nature 430: 670-673. https://doi.org/10.1038/nature02734

Pomerantz-Greenblat M. 2014. The Flint Assemblage from Abu Madi I. A PPNA Site in Southern Sinai. Unpublished MA Thesis. The Hebrew University of Jerusalem. Jerusalem. (in Hebrew) 
Rabinovich R., Nadel D. 1995. Bone tools from Ohalo II A morphological and functional study. Journal of the Israel Prehistoric Society 26: 32-63.

Ray K., Thomas J. 2018. Neolithic Britain: The Transformation of Social Worlds. Oxford University Press. Oxford.

Richter T., Bocaege E., Ilsøe P., Ruter A., Pantos A., Pedersen P., and Yeomans L. 2019. Ochre, Ground Stone, and Wrapping the Dead in the Late Epipalaeolithic (Natufian) Levant: Revealing the Funerary Practices at Shubayqa 1, Jordan. Journal of Field Archaeology 44(7): 440-457. https://doi.org/10.1080/00934690.2019.1645546

Richter T., Garrard A. N., Allcock S., and Maher L. 2011. Interaction before agriculture: Exchanging material and sharing knowledge in the final Pleistocene Levant. Cambridge Archaeological Journal 21(1): 95-114. https://doi.org/10.1017/S0959774311000060

Richter T., Stock J. T., Maher L., and Hebron C. 2010. An Early Epipalaeolithic sitting burial from the Azraq Oasis, Jordan. Antiquity 84(324): 321-334.

https://doi.org/10.1017/S0003598X00066606

Ronen A., Lechevallier M. 1991. The Natufian of Hatula. In 0. Bar-Yosef, F. R. Valla (eds.), The Natufian Culture in the Levant. International Monographs in Prehistory. Archaeological Series 1. Berghahn Books. Ann Arbor: 149160 .

1999. Save the Khiamian! Neo-Lithics 1(99): 6-7.

Rosenberg D. 2008. Serving meals making a home. The PPNA limestone vessel industry of the southern Levant. Paléorient 34(1): 23-32.

Rosenberg D., Chasan R., Lengyel G., and Nadel D. 2020. Stone 'Canvas' and Natufian Art: an incised Human Figure from the Natufian Cemetery at Raqefet Cave, Israel. $O x$ ford Journal of Archaeology 39(2): 128-140. https://doi.org/10.1111/ojoa.12189

Rosenberg D., Yeshurun R., Groman-Yaroslavski I., Winter H., Zertal A., Brown-Goodman R., and Nadel D. 2010. Huzuq Musa - A preliminary report on the test excavation at a Final Epipalaeolithic/PPNA site in the Jordan Valley. $P a$ léorient 36(2): 189-204.

Shaham D. 2014. Art Research Tools for Reading Natufian Art: A Methodological Approach and Selected Case Studies. Unpublished MA Thesis. The Hebrew University of Jerusalem. Jerusalem.

Shaham D., Belfer-Cohen A. 2013. Incised slabs from Hayonim cave: a methodological case study for reading $\mathrm{Na}-$ tufian art. In F. Borrell, J. J. Ibáñez, and Molist M. (eds.),
Stone Tools in Transition: From Hunter-Gatherers to Farming Societies in the Near East. Proceedings of the 7 th International Conference on the Chipped and Ground Stone Industries of the Pre-Pottery Neolithic. Universitat Autònoma de Barcelona Press. Barcelona: 407-419.

Shaham D., Grosman L. 2019. Engraved stones from Nahal Ein Gev II - Portraying a local style, forming cultural links. In L. Astruc, C. McCartney, F. Briois, and V. Kassianido (eds.), Near Eastern Lithic Technologies on the Move. Interactions and Contexts in Neolithic Traditions. $8^{\text {th }}$ International Conference on PPN Chipped and Ground Stone Industries of the Near East Nicosia, Cyprus. Astrom Editions. Uppsala: 133-142.

Simmons A. H. 2014. Stone Age Sailors. Paleolithic Seafaring in the Mediterranean. Left Coast Press. Walnut Creek, CA.

Simmons T., Kolska Horowitz L., and Goring-Morris A. N. 2007. "What Ceremony Else?" Taphonomy and the ritual treatment of the dead in the Pre-Pottery Neolithic B mortuary complex at Kfar HaHoresh, Israel. In M. Faerman, L. K. Horwitz, T. Kahana, and U. Zilberman (eds.), Faces from the Past: Diachronic Patterns in the Biology and Health Status of Human Populations from the Eastern Mediterranean Papers in Honour of Patricia Smith. British Archaeological Reports IS 1603. Archaeopress. Oxford: $100-126$

Snir A., Nadel D., Groman-Yaroslavski I., Melamed Y., Sternberg M., Bar-Yosef 0., and Weiss E. 2015a. The origin of cultivation and proto-weeds, long before Neolithic farming. PLoS ONE 10(7): e0131422.

https://doi.org/10.1371/journal.pone.0131422

Snir A., Nadel D., and Weiss E. 2015b. Plant-food preparation on two consecutive floors at Upper Paleolithic Ohalo II, Israel. Journal of Archaeological Science 53: 61-71. https://doi.org/10.1016/j.jas.2014.09.023

Stantis C., Kharobi A., Maaranen N., Nowell G. M., Bietak M., Prell S., and Schutkowski H. 2020. Who Were the Hyksos? Challenging Traditional Narratives Using Strontium Isotope (87sr/86sr) Analysis of Human Remains from Ancient Egypt. PLoS ONE 15(7): e0235414. https://doi.org/10.1371/journal.pone.0235414

Stekelis M., Yisraely T. 1963. Excavations at Nahal Oren Preliminary report. Israel Exploration Journal 13: 1-12.

Stutz A. J., Munro N. D., and Bar-Oz G. 2009. Increasing the resolution of the Broad Spectrum Revolution in the Southern Levantine Epipaleolithic (19-12 ka). Journal of Human Evolution 56: 294-306.

https://doi.org/10.1016/j.jhevol.2008.10.004 
Torfstein A., Goldstein S. L., Stein M., and Enzel Y. 2013. Impacts of abrupt climate changes in the Levant from Last Glacial Dead Sea levels. Quaternary Science Reviews 69: 1-7. https://doi.org/10.1016/j.quascirev.2013.02.015

Torres H. R., Groman-Yaroslavski I., Weinstein-Evron M., and Yeshurun R. 2020. A micro-wear analysis of Natufian gazelle phalanx beads from el-Wad Terrace, Mount Carmel, Israel. Journal of Archaeological Science: Reports 31: 102304. https://doi.org/10.1016/j.jasrep.2020.102304

Valla F. R. 1988. Aspects du sol de l'abri 131 de Mallaha (Eynan). Paléorient 14: 283-296.

(ed.) 2012. Les Fouilles de la Terrasse d'Hayonim (Israël) 1980-1981 et 1985-1989. De Boccard. Paris.

2019. More on early Natufian Building 131 at Eynan (Ain Mallaha), Israel. In H. Goldfus, M. I. Gruber, Y. Shamir, and P. Fabian (eds.), "Isaac went out to the field" (Genesis 24:63) Studies in Archaeology and Ancient Cultures in Honor of Isaac Gilead. Archaeopress. Oxford: 302-315.

Watkins T. 2013. The Neolithic in transition - how to complete a paradigm shift. Levant 45(2): 149-158. https://doi.org/10.1179/0075891413Z.00000000022

Weinstein-Evron M. 2009. Archaeology in the Archives. Unveiling the Natufian of Mount Carmel. Brill. Boston.
Weinstein-Evron M., Kaufman D., and Bird-David N. 2001. Rolling stones: Basalt implements as evidence for trade/ exchange in the Levantine Epipalaeolithic. Journal of the Israel Prehistoric Society - Mitekufat Haeven 31: 25-42.

Wiessner P. 1974. A functional estimation of population from floor area. American Antiquity 39: 343-349. https://doi.org/10.2307/279593

Wobst H. M. 1975. The demography of finite populations and the origins of the incest taboo. Memoirs of the Society for American Archaeology 30: 75-81.

Yaroshevich A., Bar-Yosef 0., Boaretto E., Caracuta V., Greenbaum N., Porat N., and Roskin J. 2016. A unique assemblage of engraved plaquettes from Ein Qashish South, Jezreel Valley, Israel: figurative and non-figurative symbols of Late Pleistocene hunters-gatherers in the Levant. PLoS ONE 11(8): e0160687.

https://doi.org/10.1371/journal.pone.0160687

Yeshurun R., Bar-Oz G., and Weinstein-Evron M. 2014. Intensification and sedentism in the terminal Pleistocene Natufian sequence of el-Wad Terrace (Israel). Journal of Human Evolution 70: 16-35.

https://doi.org/10.1016/j.jhevol.2014.02.011

Zbenovich V. 2006. Salvage excavations at a Pre-Pottery Neolithic site at Modi'in. 'Atiqot 51: 1-15. 